\title{
当科におけるスポーツ外傷手術症例の検討 （特に前十字勒帯，前距腓勒帯損傷を中心に）
}

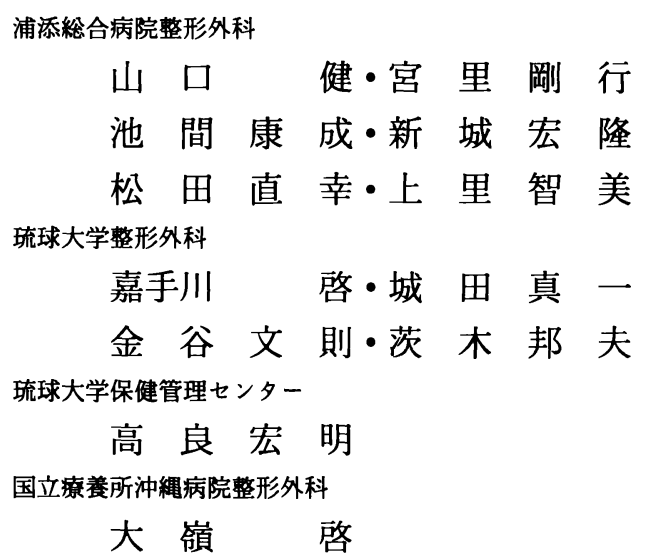

\section{Surgical Treatment of ACL and ATF Injuries in Athletes by \\ Takeshi Yamaguchi, Takeyuki Miyazato, Yasunari Ikema, Hirotaka Sinjo, Naoyuki Matsuda and Tomomi Uesato Department of Orthopaedic Surgery, Urasoe General Hospital}

Kei Kadekawa, Shinichi Shirota, Fuminori Kanaya and Kunio Ibaraki

Department of Orthopaedic Surgery, School of Medicine, University of the Ryukyus

\section{Hiroaki Takara}

Health Administration Center, University of the Ryukyus

\section{Akira Ohmine}

Department of Orthopaedic Surgery, National Okinawa Hospital

We studied 415 cases of ACL and 226 cases of ATF injuries in order to analyze the relationship between the causative incident and the patient's physical characteristics. We classified each case into two groups : contact or non-contact conditions. To study the physical characteristics we measured the tibial plateau angle and notch width index (NWI) of the knee and A-P mortice angle of the ankle on X-ray films and also the patient's joint laxity score. In the non-contact group of ACL injuries, the tibial plateau angle was greater ( $p<0.05$ in male, $p<0.01$ in female), NWI was smaller $(p<0.01$ in male and female) and the joint laxity score was higher $(p<0.05$ in male, $p<0.01$ in female) than the control group. In the non-contact group of ATF injuries, the A-P mortice angle was smaller ( $p<0.01$ in male, $p<0.05$ in female) and the joint laxity score was higher $(p<0.05$ in female) than the control group. In this study, it was suggested that knee and ankle shape and joint laxity were important factors in ACL and ATF injuries. To prevent ACL and ATF injuries, we 
recommend physical examination to help athletes understand the importance of these physical characteristics.

Key words : anterior cruciate ligament injury（前十字靱帯損傷), anterior talofibular ligament injury（前距腓靬帯損傷), physical characteristics（身体的特性）

はじめに

当科において平成 5 年 8 月より平成 8 年 7 月までに スポーツ外傷で手術を行った 947 例の中で，前十字靱 帯 (以下 ACL) と前距腓靯帯 (以下 ATF) 損傷例の 受傷機転と身体的特性について検討したので報告する.

\section{対}

象

$\mathrm{ACL}$ 損傷は 415 例（男性 231 例，女性 184 例), 平 均年齢は男性 25.1 才，女性 20.1 才，平均観察期間は 2 年 4 カ月であった。 ATF 損傷は 226 例（男性 110 例，女性 116 例)，平均年齢は男性 20.0 才，女性 17.0 才，平均観察期間は 1 年 2 力月であった，対象はすべ てスポーツ外傷で, 受傷種目は男性，女性ともにバス ケットが最す多かった（図1）.
方法

ACL 損傷群では, 術後評価として, 前方引き出し テスト（以下 ADT), Lachmanテスト， Nテスト， KT-2000による患健側差の測定を行った，身体的特 性の検討のため受傷機転および東大式関節弛緩性テス 卜 7 項目（以下 Laxity score）を調べ, 単純レント ゲン撮影で脛骨高原後傾角と notch width index （以下 NWI）を測定した。脛骨高原後傾角は膝関節レ ントゲン側面像における脛骨前縁の延長線上に立てた 垂線と脛骨膝関節面とのなす角で（図 $2 \mathrm{~A}$ ), NWI は 顆間穸撮影の画像で内外顆の幅 $\mathrm{a}$ と顆間窩幅 $\mathrm{b}$ を計 測し，bを a で除した值を用いた（図 2 B）.

$\mathrm{ATF}$ 損傷群では術後評価として, 足関節の内反 トレス撮影にて距骨傾斜角を測定した，身体的特性の 検討のため受傷機転および Laxity score, 単純レン

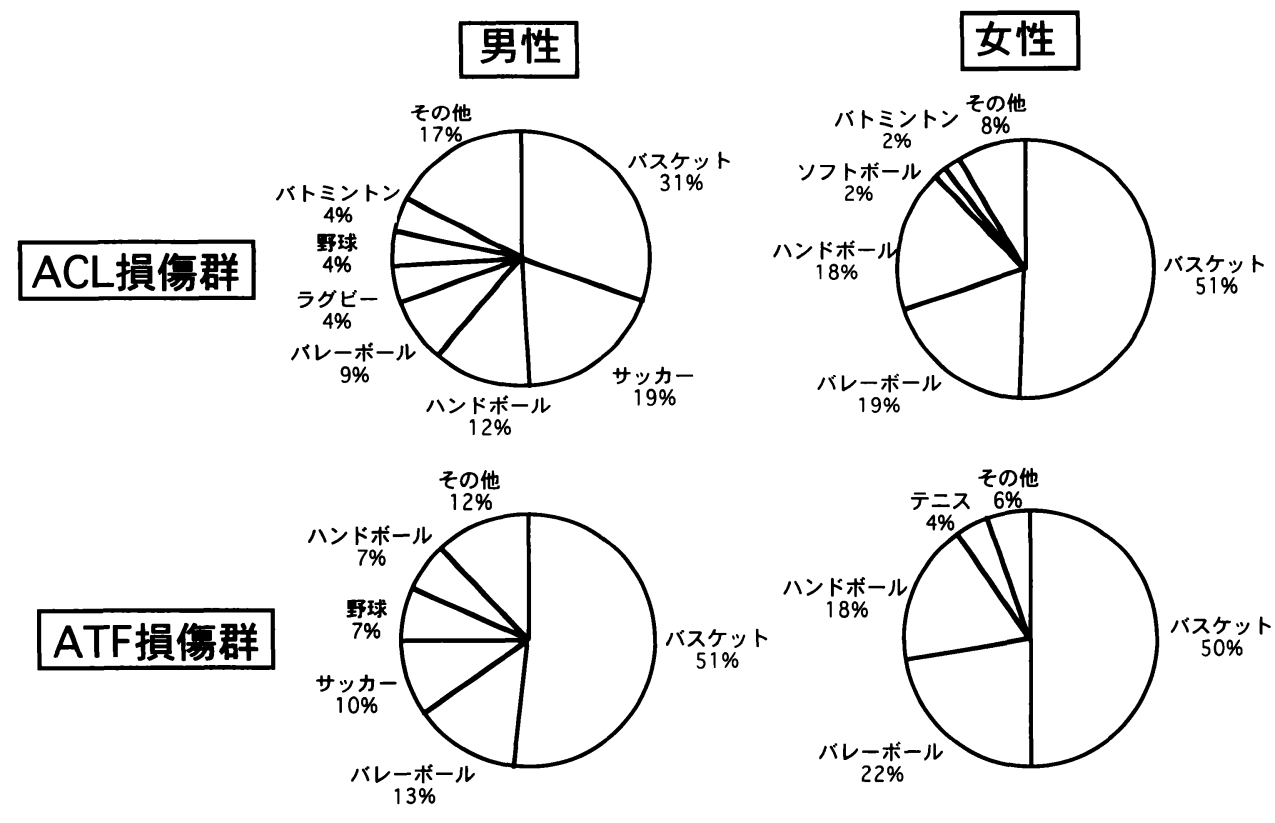

図 $1 \mathrm{ACL}, \mathrm{ATF}$ 損賃群の受傷種目とその割合 

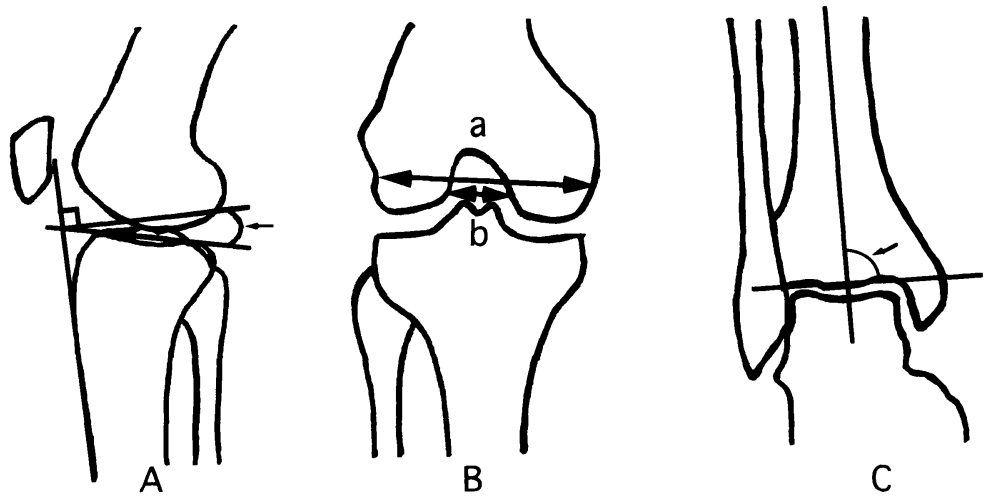

$\begin{aligned} & \text { 図 } 2 \text { レントゲン計測 } \\ & \text { A : 脛骨高原後傾角 (知印) } \\ & \text { B : NWI }(b / a) \\ & \text { C : 足関節正面天蓋角（矢印） }\end{aligned}$

トゲン撮影より足関節正面天蓋角を測定した．足関節 正面天蓋角は足関節正面像で脛骨の長軸と脛骨関節面 とのなす角度を測定した（図 $2 \mathrm{C}$ ).

尚, Laxity score は ACL 損傷群では男性 88 例, 女性 103 例, ATF 損傷群では男性 33 例，女性 46 例 のみ測定した.

また，コントロール群として脛骨高原後傾角および NWI では ACL 損傷のない外来患者 120 人（男性 60 人，女性 60 人），平均年齢 24.1 才（男性 25.2 才，女 性 22.6 才）を用い，足関節正面天蓋角は ATF 損傷 のない外来患者 120 人（男性 60 人，女性 60 人），平 均年齢 20.8 才（男性 20.8 才，女性 20.7 才）を用い た. Laxity score では障害のない, 高校バスケット 選手 252 人（男性 163 人，女性 89 人），平均年齢男女 ともに 16.5 才を用いた.

\section{結果}

\section{1) 術後評価}

ACL 損傷群の術後評価は，男女とも ADT， Lachman テスト， N テストの陽性率は $10 \%$ 以下とな り, KT-2000 の患健側差は男性で術前 $3.8 \mathrm{~mm}$ が術 後 $0.3 \mathrm{~mm}$ へ( $\mathrm{p}<0.01)$, 女性で $3.9 \mathrm{~mm}$ が $0.3 \mathrm{~mm}$ へ $(p<0.01)$ 有意に減少した.

$\mathrm{ATF}$ 損傷群の術後評価で距骨傾斜角は男性で術前 14.2 度が術後 2.1 度へ（p<0.01），女性で 16.4 度が 4.4 度へ $(\mathrm{p}<0.01)$ 有意に改善した。

2 ) 身体的特性の検討
身体的特性の検討を行うために各損傷群を受傷時に 他の選手と接触があった接触群之接触がなかった非接 触群に分けた. ACL 損傷群において男性で接触群は $40.2 \%$, 非接触群は $59.8 \%$, 女性で接触群は $21.7 \%$, 非接触群は $78.3 \%$ であった. ATF 損傷群において男 性で接触群は $47.9 \%$, 非接触群は $52.1 \%$ であった。 女性で接触群は $36.7 \%$ ，非接触群は $63.3 \%$ であった。

まず ACL 損傷と脛骨高原後傾角との関連性を検討 した. 男性で脛骨高原後傾角の平均値は接触群, 非接 触群とす 14.9 度, コントロール群は 13.6 度であり, 非接触群はコントロール群より有意に大きかった（p $<0.05)$. 女性で接触群は 12.7 度, 非接触群は 13.8 度, コントロール群は 12.3 度であり, 非接触群はコ ントロール群より有意に大きかった（p<0.01）（図 $3 \mathrm{~A})$.

次に ACL 損傷と NWI との関連性を検討した。 男 性の NWI の平均值は接触群で 0.27 , 非接触群で 0.29 , コントロール群で 0.31 であり, 接触群, 非接 触群ともコントロール群より有意に小さかった（ $\mathrm{p}<$ 0.01 )。女性では接触群で 0.31 , 非接触群で 0.29 , コ ントロール群で 0.32 であり, 非接触群はコントロー ル群より有意に小さかった $(\mathrm{p}<0.01)$ (図 $3 \mathrm{~B}$ ).

さらに ACL 損傷と関節弛緩性との関連について検 討した. Laxity score の平均值は 7 点中, 男性で ACL 損傷群は 2.61，コントロール群は 2.56 であっ た. 女性で ACL 損傷群は 4. 43, コントロール群は 3. 43 であった。 また全身関節弛緩症といわれる， 


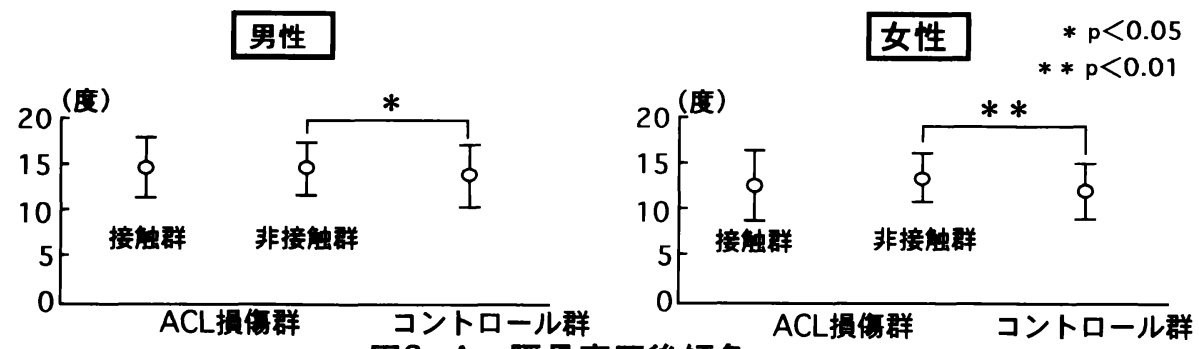

図3-A 䀴奥高原後傾角
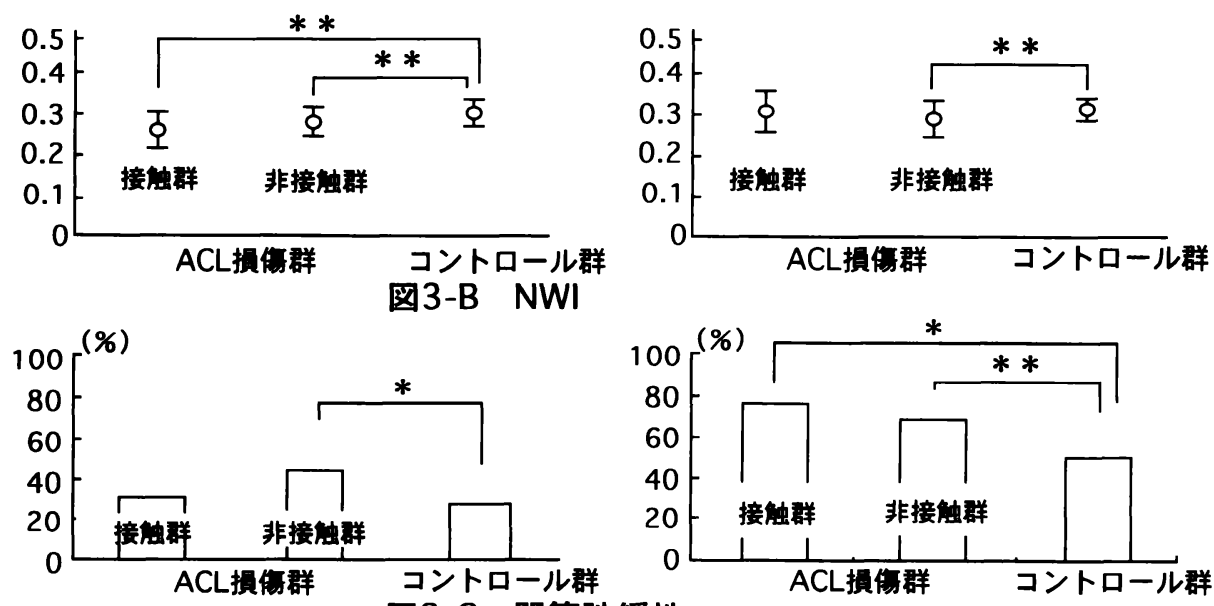

图3-C 関節驰緩性

図 $3 \mathrm{ACL}$ 損傷之脛骨高原後傾角, NWI, 関節弛緩性の関連

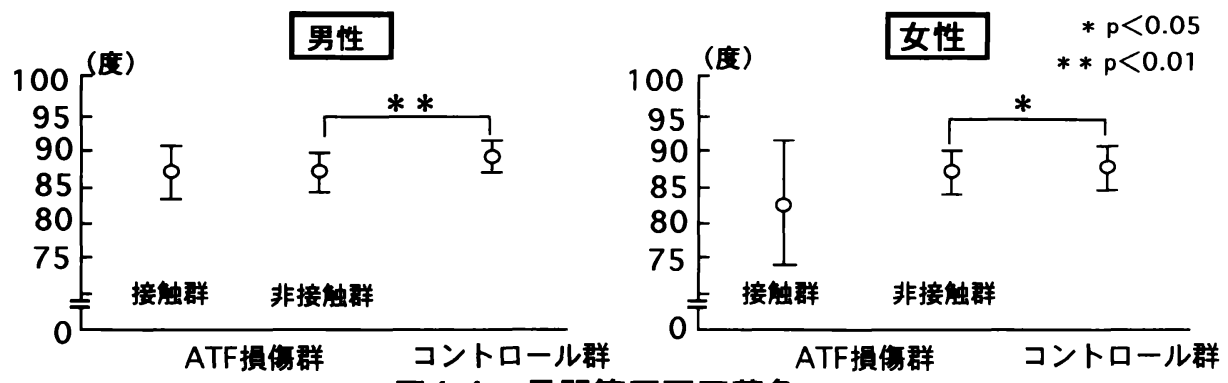

図4-A 足関節正面天蓋角
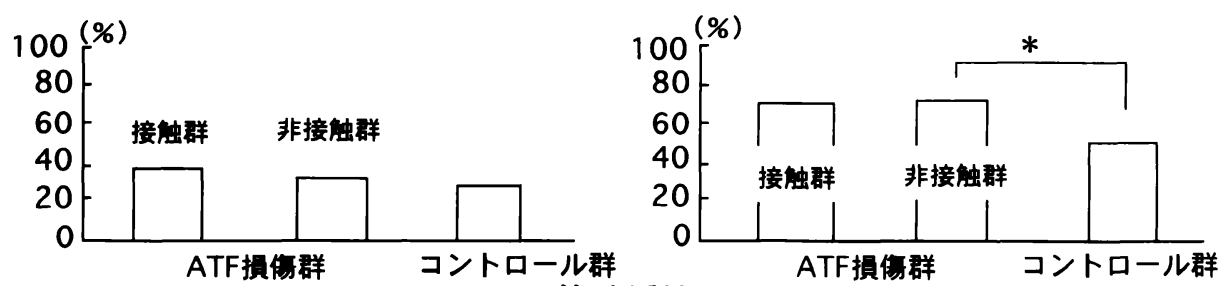

図4-B 関節弛緩性

図 4 ATF 損傷と足関節正面天蓋角, 関節弛緩性 
Laxity score 4 点以上が各群に占める割合を比較する

と, 男性で接触群は $32.4 \%$, 非接触群は $44.4 \%$, コ ントロール群は $27.8 \%$ であった。 女性で接触群は $77.3 \%$, 非接触群は $67.9 \%$, コントロール群は 51.2 \%であった. 各群間でカイ 2 乗検定を行うと男性で非 接触群とコントロール群, 女性で接触群, 非接触群と あにコントロール群と有意差を認めた（図 $3 \mathrm{C}$ ).

ATF 損傷之足関節正面天蓋角との関連性について 検討した，足関節正面天蓋角の平均値は男性で接触群 は 87.0 度, 非接触群は 86.8 度, コントロール群は 89.2 度であった. 非接触群はコントロール群と比べ 有意に小さかった $(\mathrm{p}<0.01)$. 女性で接触群は 81.4 度, 非接触群は 87.0 度, コントロール群は 88.0 度で あった．非接触群はコントロール群と比べ有意に小さ かった ( $<<0.01)$ (図 4 A).

次に ATF 損傷之関節弛緩性との関連性について検 討した. Laxity score の平均値は, 男性で ATF 損 傷群は 2.67 , コントロール群は 2.56 であった。 女性 で ATF 損傷群は 4.39, コントロール群は 3.43 であっ た. また, 各群の Laxity score 4 点以上の割合は男 性で接触群は $37.5 \%$, 非接触群は $31.2 \%$, コントロー ル群は $27.8 \%$ であった，女性で接触群は $70.6 \%$, 非 接触群は $72.2 \%$, コントロール群は $51.2 \%$ であった。 各群間のカイ 2 乗検定では, 女性の非接触群とコント ロール群のみに有意差を認めた（ $\mathrm{p}<0.05 ）$ (図 $4 \mathrm{~B}$ ).

\section{考察}

ACL 損傷について增島ら ${ }^{1)}$ は脛骨高原後傾角が增 せば ACL 損傷が起きやすくなる, Souryalら ${ }^{3)}$ は非 接触群はコントロール群よりも NWI が小さい, 中嶋 ら 2) は ACL 損傷者は全身関節弛緩性が高いとそれぞ れ報告している，また，ATF 損傷に関しても高倉 ら ${ }^{4)}$ が脛骨下端関節面の内反傾向を有する足関節は外
側勒帯損傷を受けやすいと報告している.

今回の結果, $\mathrm{ACL}, \mathrm{ATF}$ 損傷群とも諸家の報告と 同様の結果が得られた。 また，新たに ATF 損傷と関 節弛緩性との関連も示唆された。

$\mathrm{ACL}, \mathrm{ATF}$ 損傷が発生する要因としては，膝およ び足関節の形態的特徴や関節弛緩性が関与しているこ とが考えられ，スポーツ競技者にメディカルチェック を行い，身体的特性を理解させることは ACL，ATF 損傷予防の一助となると考えられる。

$$
\text { ま と め }
$$

1）当科におけるスポーッ外傷手術症例の中で ACL と ATF 損傷例の受傷機転と身体的特性につい て検討した.

2) ACL 損傷群では，非接触群で脛骨高原後傾角 が大きく，NWI が小さく，Laxity score が高かった.

3) ATF 損傷群では, 非接触群で足関節正面天蓋 角が小さく, Laxity score が高かった.

4) ACL，ATF 損傷が発生する要因としては, 膝 および足関節の形態的特徴や関節弛緩性が関与してい ると考えられる。

\section{参考 文 献}

1）增島 篤ら：女子バスケットボールの前十字靶帯損傷 (第 2 報). 昭和 61 年度日本体育協会スポーツ医科学研 究報告, $9: 34-39,1987$.

2）中嶋寛之ら：女子体操における前十字勒帯損賃. 整形・ 災害外科, $27: 609-613,1984$.

3) Souryal TO et al. : Intercondylar notch size and anterior cruciate ligament injuries in athletes. Am J Sports Med, $21: 535-539,1993$.

4）高倉義典ら：スポーッ外傷における足関節勒帯損賃. MB Orthop. 7(4) : 51-55, 1994. 